\title{
Difference in F2 Isoprotane Levels in Male Model Mice (Mus musculus L.) in Maximum Physical Exercise Without Supplementation
}

\author{
Elsa Yuniarti ${ }^{1, *}$ Des $\mathrm{M}^{1}$ Pudia M.Indika ${ }^{2}$
}

\author{
${ }^{1}$ Dept. of Biology, Faculty of Mathematics and Science (FMIPA), Universitas Negeri Padang, Padang, Indonesia \\ ${ }^{2}$ Health and Recreation Department Faculty of Sport Science (FIK), Universitas Negeri Padang, Padang, \\ Indonesia \\ *Corresponding author. Email: elsayuniarti@gmail.com
}

\begin{abstract}
Vigorous physical exercise that exceeds the limit of fatigue can increase the formation of free radicals that lead to oxidative stress. One of the biomarkers used to determine the presence of oxidative stress is the level of F2isoprostane. This study aims to determine the differences in levels of F2-isoprostan in male model mice (Mus musculus L.) in maximum physical exercise without supplementation. This research is an experiment. The population in this study were 30-35gram male mice aged 8-10 weeks. Based on the provisions in the study, the sample was 30 male mice that met the criteria. Examination of samples using ELISA reader and data processed in tables and graphs. The results of statistical tests obtained $\mathrm{p}$ value $<0.05$ ( $\mathrm{p}<0.01$ ), it can be concluded that there is a difference in F2-isoprostane levels between the groups that were not given weight training and those who were given maximum weight training. Where the levels of F2-isoprostane given maximum weight, training were 2 times greater than those not given weight training.
\end{abstract}

\section{Keywords: $f 2$ isoprostane, Mus musculus, maximum physical exercise}

\section{INTRODUCTION}

Physical exercise is body movement performed by muscles in a planned, structured and repetitive manner that causes energy use to improve physical fitness [1]. Regular physical exercise has beneficial effects on health, including reducing and preventing various cardio vascular diseases, metabolic syndrome disorders (diabetes mellitus, hypertension, obesity) and osteoporosis [2].

In addition to having a positive effect, physical exercise can have a negative effect, which is inhibiting or damaging if physical exercise is carried out until fatigue is called maximum physical exercise [3]. The impact of excessive physical exercise is that there is an imbalance between physical exercise and recovery time. Excessive physical exercise can have a negative effect on the body's homeostatic condition, which in turn affects the body's organ work system [4]. Excessive doses or doses of exercise can cause pain or injury and even cause death. Meanwhile, the dose or dose of exercise that is small or does not reach the training zone, does not bring benefits to health $[5,6]$.
Heavy physical exercise that exceeds the limit of fatigue can increase the formation of free radicals through increased reduction of oxygen in the mitochondria, increased metabolism of epinephrine and catecholamines, increased activity of leukocytes and macrophages in areas where reperfusion injury, increased xanthine oxidase, increased activity of NADPH (nicotinamide adenine dinucleotide phosphate), oxidase and cytochrome P.450 [1].

The high metabolic rate and lack of oxygen supply during strenuous physical exercise will stimulate the release of free radicals that are incorporated, especially superoxide radicals in Reactive Oxygen Species (ROS) [1,7]. In this condition, free radicals will cause lipid peroxidation in the cell membrane and damage the cell membrane organization. Lipid peroxidation in cell membranes makes it easier for erythrocyte cells to undergo hemolysis, which is the occurrence of lysis on the erythrocyte membrane which causes oxidation of 
haemoglobin and ultimately causes haemoglobin levels to decrease [8].

Free radicals are highly reactive molecules and their excess will result in oxidative stress which can cause damage to the endothelial cell walls of blood vessels and ultimately act as a cause of various chronic diseases, muscle damage and decreased immune function that can affect exercise performance $[1,6]$. Oxidative stress is one of the factors causing erythrocyte damage during and after maximal physical exercise. From the research that has been done, the damage to erythrocytes that occurs during and after maximum physical exercise can cause anemia which is often called sports anemia [9]. One of the biomarkers used to determine the presence of oxidative stress is the level of F2-isoprostan, which is the end product of lipid peroxidation in the body due to free radicals [10]. F2-isoprostane increases with physical exercise and may reflect oxidative stress on cell membranes during muscle activity. In healthy men, F2-isoprostane increased 2-4fold in urine after light-intensity exercise, 4-fold after submaximalintensity exercise and 7-fold after vigorous-intensity exercise. The increase in F2-isoprostane is associated with a decrease in athlete's performance in an effort to increase performance [11].

Therefore, the aim of this study was to determine the differences in levels of F2 isoprostane in the male model of male mice (Mus musculus L.) at maximum physical exercise without supplementation.

\section{MATERIALS AND METHODS}

\subsection{Research location and design}

This research was conducted at the Laboratory of Animal Physiology, Department of Biology, Faculty of Mathematics and Natural Sciences, UNP. This research uses experimental research type.

\subsection{Method of collecting data}

Data collection of F2 isoprostane levels was carried out on blood samples of male mice that were treated (maximum physical exercise) and without treatment (without physical exercise), where the number of samples was 30 male mice, then the blood was processed into serum and then the F2 level was checked using ELISA technique. using an ELISA kit (Elabscience).

\subsection{Procedure}

Mice were acclimatized for 7 days at room temperature before being treated. The rats were fed in the form of pellets and bottled water. Mice were then divided into 2 groups, $\mathrm{K} 1$; the group without physical training, K2; group with maximum physical exercise. Each group consists of 15 mice. Maximum physical exercise group was given treatment in the form of maximum swimming. The maximal physical exercise treatment procedure followed the procedure performed by [12] Meanwhile, the rat swimming pool follows [8] which is a cube. Mice were taken from the K2 treatment group randomly for maximum physical exercise by means of mice being forced to swim in a container without bulkhead with a size of $32(\mathrm{w}) \times 16(\mathrm{l}) \times 24(\mathrm{t}) \mathrm{cm}$ filled with water with a depth of $8 \mathrm{~cm}$. After the rats were put into the container, a stopwatch was used to calculate the time required for maximum physical exercise. In an attempt to get out of the container the rats swim, dive and climb the walls of the container with all their strength and if the mice appear to be resting to draw energy, they are soaked using tweezers. When the mouse stopped all movement, except for survival (keeping the head above the water), it was considered to have performed maximal physical exercise [12] Maintenance of swimming gymnastics is carried out with a maximum frequency of exercises 3 times a week for 28 days with a swimming duration of 30 minutes.

\subsection{Data Analysis}

The results of the examination of F2 isoprostane levels were analyzed using paired sample t-test with a significant value if $\mathrm{p}<0.001$.

\section{RESULT AND DISCUSSION}

In this study, it was found that the average level of F2 isoprostane in the male model mice (Mus musculus L.) without physical exercise was $9 \mathrm{ng} / \mathrm{L}$, an increase of $95 \%$ after physical exercise, the maximum was $18 \mathrm{ng} / \mathrm{L}$. The distribution of the average F2 isoprostane without physical exercise and maximum physical exercise in the male mouse model can be seen in Figure 1. 


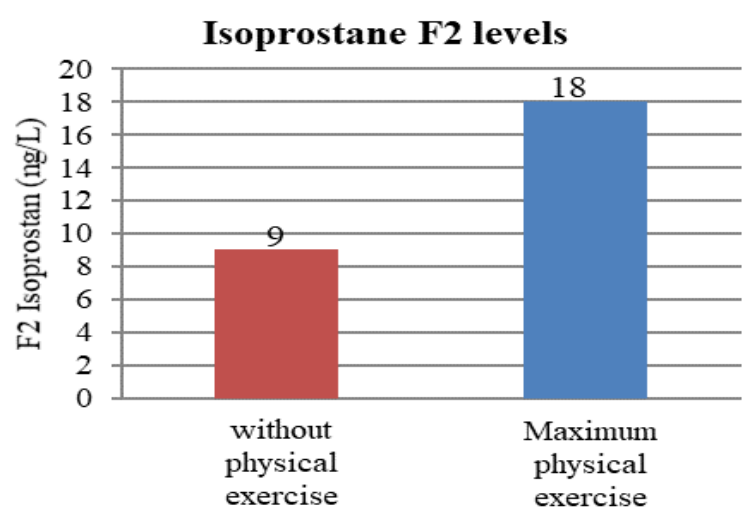

Figure1. Isoprostane F2 levels in the male model of mice (Mus musculus L.). Note: The $\mathrm{p}$ value $<0.001$ indicates a significant difference in the level of F2 isoprostane without physical exercise and maximum physical exercise.

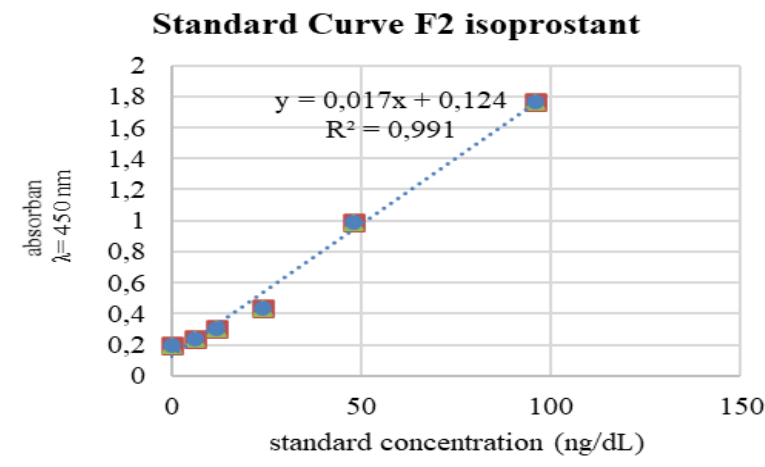

Figure 2. Standard curve of F2 isoprostane

In Table 1, the level of F2 isoprostane without physical exercise is $9.28 \pm 0.68 \mathrm{ng} / \mathrm{L}$ and maximum physical exercise is $18.06 \pm 2.55 \mathrm{ng} / \mathrm{L}$. The difference between the measurement of F2 isoprostane without physical exercise and physical exercise was a maximum of $8.78 \mathrm{ng} / \mathrm{L}$. The statistical test results obtained $p$ value $<0.05$ ( $p<0.01)$, it can be concluded that there is a difference in F2-isoprostan levels between the groups that were not given weight training and those who were given maximum weight training. Where the levels of F2-isoprostane given maximum weight, training were 2 times greater than those not given weight training.

This situation is consistent with research by [13] using an ultramarathon athlete model, showing a significant increase in F2-isoprostane levels in 13 ultramarathon runners in a $32 \mathrm{~km}$ race. The level of F2-isoprostane before the competition averaged 44.8 $\pm 2.8 \mathrm{pg} / \mathrm{ml}$, increasing to $62.6 \pm 2.8 \mathrm{pg} / \mathrm{ml}$. The same thing also happened to strenuous physical exercise. This was evident in 11 athletes ( 3 women, 8 men) studied during a $50 \mathrm{~km}$ marathon the levels of F2isoprostan increased by $57 \%$ after the race. Levels of F2-isoprostane increased from $75 \pm 7 \mathrm{pg} / \mathrm{ml}$ before the marathon and $131 \pm 17 \mathrm{pg} / \mathrm{ml}$ after the marathon then returned to baseline 24 hours after the marathon [14].

The [4] research on a model of PPLP high school students with various sports showed an increase in F2 isoprostane $37 \%, 38 \mathrm{pg} / \mathrm{ml}$ before physical exercise and $52 \mathrm{pg} / \mathrm{ml}$ after submaximal physical exercise. [15] also found an increase in F2 isoprostane in the West Sumatra education and training center student model before physical exercise $35.3 \pm 15.1 \mathrm{pg} / \mathrm{ml}$ and after submaximal physical exercise $48.2 \pm 16.9$ $\mathrm{pg} / \mathrm{ml}$.

Several studies above have proven that maximum physical exercise can increase the production of free radicals. In theory, free radicals can be formed during and

Table 1. The results of the unpaired t-test $\mathrm{F} 2$ isoprostane blood of mice (Mus musculus L.) without physical exercise and which were given maximum physical exercise treatment

\begin{tabular}{lccc}
\hline & n & $\begin{array}{c}\text { Average } \\
\mathbf{1 S D}\end{array}$ & $\mathbf{P}$ \\
\hline $\begin{array}{l}\text { without } \\
\text { physicalexercise }\end{array}$ & 15 & $9,28 \pm 0,68$ & $<0,001$ \\
$\begin{array}{l}\text { Maximum physical } \\
\text { exercise }\end{array}$ & 15 & $18,06 \pm 2,55$ & \\
\hline
\end{tabular}

after physical exercise by contracted muscles and ischemic-reperfused tissues. When the rate of free radical formation increases beyond the capacity of the antioxidant defense system. These free radicals can initiate lipid peroxidation directly against polyunsaturated fatty acids in the cell walls so that they damage cell membranes and if excess can cause damage to the endothelial cell walls of blood vessels and ultimately have a role in causing various chronic diseases, muscle damage and immune function. reduced so as to affect exercise performance [1] [6]. One of the biomarkers used to determine the presence of oxidative stress is the level of F2-isoprostan, which is the end product of lipid peroxidation in the body due to free radicals. F2-isoprostane increases with physical exercise and may reflect oxidative stress on cell membranes during muscle activity [10].

\section{CONCLUSION}

The statistical test results obtained $\mathrm{p}$ value $<0.001$, it is concluded that there is a very significant effect between F2 isoprostane without physical exercise and maximum physical exercise. Where the levels of F2-isoprostane given maximum weight, training were 2 times greater than those not given. 


\section{ACKNOWLEDGMENT}

This study was supported by Penelitian Dasar PNBP Universitas Negeri Padang.

\section{REFERENCES}

[1] S.K. Powers, M.J. Jackson, Exercise-induced oxidative stress: cellular mechanisms and impact on muscle force production, Physiological reviews, 88(4) (2008) 1243-1276. DOI:

https://doi.org/10.1152/physrev.00031.2007

[2] B.K. Pedersen, L. Hoffman-Goetz, Exercise and the immune system: regulation, integration, and adaptation. Physiological reviews 80(3) (2000) 1055-1081.

DOI: https://doi.org/10.1152/physrev.2000.80.3.1055

[3] A.C. Sianturi, Pengaruh Pemberian Ekstrak Air Daun Bangun-Bangun (Coleus amboinicus L) Terhadap Jumalah Sel Darah Merah dan Hemoglobin Pada Tikus Putih (Rattus norvegicus) yang diberi Aktivitas Fisik Maksimal, Undergraduate thesis, Universitas Negeri Medan, 2011. [In Bahasa Indonesia]

[4] E. Yuniarti, A. Afriwardi, Pengaruh Latihan Fisik Submaksimal Terhadap Kadar F2Isoprostan pada Siswa Pusat Pendidikan dan Latihan Olahraga Pelajar Sumatera Barat. Eksakta. Vol.1, 2015, pp.16-21. [In Bahasa Indonesia]

[5] L. Sherwood, Human physiology: from cells to systems. Cengage learning, 2015.

[6] J. Fridén, R.L. Lieber, M. Hargreaves, A. Urhausen, Recovery after TrainingInflammation, Metabolism, Tissue Repair and Overtraining. Textbook of Sports Medicine: Basic Science and Clinical Aspects of Sports Injury and Physical Activity, 2003, pp.189-200.

[7] P.M. Clarkson, H.S. Thompson, Antioxidants: what role do they play in physical activity and health?, The American journal of clinical nutrition. 72(2) (2000) 637-646. DOI: https://doi.org/10.1093/ajen/72.2.637S

[8] R.H. Simanullang, Pengaruh Vitamin C Sebelum Latihan Fisik Maksimal Terhadap Kualitas Eritrosit Mencit Jantan (Mus Musculus) Strain DD Webster, Doctoral Dissertation, 2009. [In Bahasa Indonesia]
[9] U.K. Şentürk, F. Gündüz, O. Kuru, M.R. Aktekin, D. Kipmen, O. Yalçin, M. BorKüçükatay, A. Yeşilkaya, O.K. Başkurt, Exercise-induced oxidative stress affects erythrocytes in sedentary rats but not exercisetrained rats, Journal of applied physiology 91(5) (2001) 1999-2004. DOI: https://doi.org/10.1152/jappl.2001.91.5.1999

[10] L. Packer, editor. Handbook of antioxidants. CRC Press. 2001.

[11] K. Margonis, I.G. Fatouros, A.Z. Jamurtas, M.G. Nikolaidis, I. Douroudos, A. Chatzinikolaou, A. Mitrakou, G. Mastorakos, I. Papassotiriou, K. Taxildaris, D. Kouretas, Oxidative stress biomarkers responses to physical overtraining: implications for diagnosis, Free Radical Biology and Medicine 43(6) (2007) 901-910. DOI: https://doi.org/10.1016/j.freeradbiomed.2007.05 .022

[12] L. Ciulla, H.S. Menezes, B.B.M. Bueno, A. Schuh, R.J.V. Alves, M.P. Abegg, Antidepressant behavioral effects of duloxetine and fluoxetine in the rat forced swimming test, Acta cirurgica brasileira 22(5) (2007) 351-354. DOI: $\underline{86502007000500005}$

[13] F.M. Palmer, D.C. Nieman, D.A. Henson, S.R. McAnulty, L. McAnulty, N.S. Swick, A.C. Utter, D.M. Vinci, J.D. Morrow, Influence of vitamin $\mathrm{C}$ supplementation on oxidative and salivary $\operatorname{Ig} \mathrm{A}$ changes following an ultramarathon, European journal of applied physiology 89(1) (2003) 100-107. DOI: https://doi.org/10.1007/s00421-002-0756-4

[14] A. Mastaloudis, S.W. Leonard, M.G. Traber, Oxidative stress in athletes during extreme endurance exercise, Free Radical Biology and Medicine 31(7) (2001) 911-922. DOI: https://doi.org/10.1016/S0891-5849(01)00667-0

[15] M. Syahrastani, D.H. Putri, E. Yuniarti, The Impact of Submaximal Exercise on F2Isoprostan and Il-6 Levels on the Student of Student Center for Education and Training West Sumatra, International Journal of Mechanical Engineering and Technology 10(12) (2019) 174-181. 